\title{
Transdural Segment of the Radicular Vein in Spinal Dural Arteriovenous Fistula
}

\author{
Su Hee Cho, MD, Dae Chul Suh, MD
}

Spinal dural arteriovenous fistula (SDAVF) is the most common spinal vascular shunt lesion $[1,2]$. SDAVF confines to the lateral group of the epidural spinal shunt which corresponds to DAVFs in the marginal sinus (lateral portion-foramen magnum) with the emissary-bridging vein to the condyloid vein, falcotentorial (vein of Galen), petrosal and basitentorial, Breschet sinus, paracavernous region (embryonic tentorial sinus remnants), intraorbital shunts, and lamina cribriformis [3].

Development of the intrinsic venous drainage of the spinal cord starts after closure of the neural tube [4]. Two longitudinal collector systems form in the subarachnoid space at the dorsal and ventral surface of the cord, later joining the epidural space laterally through numerous emissary-bridging veins. Contrary to arteries, these veins are not embryologically (metamerically) linked with the spinal nerves and thus do not follow a nerve root nor do they exit the subarachnoid space with them $[3,5,6]$. Up to $40 \%$ of them exit through a separate dural foramen between the spinal nerves; thus, they should not be confused with the

All authors: Department of Radiology, Asan Medical Center, University of Ulsan College of Medicine, Seoul, Korea

Received February 24, 2017;

accepted after revision February 28, 2017.

Correspondence to: Dae Chul Suh, MD, PhD, Department of Radiology, Asan Medical Center, University of Ulsan College of Medicine, 88, Olympic-ro 43-gil, Songpa-gu, Seoul 05505, Korea

Tel. 82.2.3010.4366 Fax. 82.2.2045.4127

E-mail: dcsuh@amc.seoul.kr

This is an Open Access article distributed under the terms of the Creative Commons Attribution Non-Commercial License (http://creativecommons.org/licenses/by-nc/3.0) which permits unrestricted non-commercial use, distribution, and reproduction in any medium, provided the original work is properly cited. minute radicular veins draining the roots [3]. They may instead be named emissary-bridging veins (transdural) to differentiate them from the so-called emissary veins (transosseous), which drain the intracranial venous sinuses outside of the skull.

Two structurally distinct arrangements of the transdural segment of the radicular vein could be identified: A slit type was seen in $60 \%$ of the veins studied and a bulge- or nodular type was seen in $35 \%$ of the veins [7]. Different arrangements of the transdural course of the veins appear to be at least appropriate to modulate flow. The caliber of the vessel decreases at its transdural course [7]. The normal composition of the vessel wall gradually gets lost and is replaced by dural tissue and a layer of arachnoid. There was no venous valve except anti-backflow system within the transdural course of the radicular vein, resulting from narrowing and zigzagging of the vein while crossing the dura $[7,8]$.

The radicular vein is being regarded as a venous drainage route in SDAVF [2]. Outflow obstruction of its adjacent venous outlet, either due to thrombosis or fibrosis related to aging, will then lead to immediate drainage into the perimedullary veins [2]. This venous diversion or reflux induces venous congestive myelopathy $[9,10]$. Although there is only one feeder in most cases, the reason why there are sometimes plexiform multiple channels in SDAVF is uncertain. Such multiple channels of shunts in SDAVF may results in difficult penetration of embolic agent into the fistula point due to the regurgitation of liquid embolic agents [11]. Multiple collateral channels in spinal column are also concerns during embolization of spinal vascular lesions [12]. Such complex vascular anatomy requires $3 \mathrm{D}$ angiographic analysis to evaluate angioarchitecture 


\section{Su Hee Cho, et al.}

and also to scrutinize for a concomitant origin of the radiculomedullary or radiculopial arteries that supply the spinal cord $[11,13]$.

The emissary-bridging vein of the rhombencephalon is the medullary vein opening laterally into the condyloid vein at the level of the foramen magnum [3]. The basal vein anastomotic circle; its afferent veins; and its mesencephalic, cavernous, and galenic (telencephalic and diencephalic) outlets are the cranial homologs of the emissary-bridging veins of the hindbrain and spinal cord [14]. Cortical venous reflux is encountered in high-flow shunts forcing the emissary-bridging vein or equivalent veins opening after reflux in the lateral epidural space $[5,6,15]$.

\section{References}

1. Park JE, Koo HW, Liu H, Jung SC, Park D, Suh DC. Clinical Characteristics and Treatment Outcomes of Spinal Arteriovenous Malformations. Clin Neuroradiol 2016

2. Krings T, Geibprasert S. Spinal dural arteriovenous fistulas. AJNR Am J Neuroradiol 2009;30:639-648

3. Geibprasert S, Pereira V, Krings T, Jiarakongmun P, Toulgoat F, Pongpech $\mathrm{S}$, et al. Dural arteriovenous shunts: a new classification of craniospinal epidural venous anatomical bases and clinical correlations. Stroke 2008;39:2783-2794

4. Lasjaunias P, Berenstein A, Ter Brugge KG. 2. Spinal and spinal cord arteries and veins. Surgical neuro-angiography. New York: Springer; 2001:73-164.

5. Zhao LB, Suh DC, Lee DG, Kim SJ, Kim JK, Han S, et al. Association of pial venous reflux with hemorrhage or edema in dural arteriovenous fistula. Neurology 2014;82:1897-1904

6. Suh DC, Lee JH, Kim SJ, Chung SJ, Choi CG, Kim HJ, et al. New concept in cavernous sinus dural arteriovenous fistula:
Correlation with presenting symptom and venous drainage patterns. Stroke 2005;36:1134-1139

7. Thron A, Krings T, Otto J, Mull M, Schroeder JM. The Transdural Course of Radicular Spinal Cord Veins--A Microangiographical and Microscopical Study. Clin Neuroradiol 2015;25:361-369

8. Krings T, Coenen VA, Weinzierl M, Reinges MH, Mull M, Thron A, et al. Spinal dural arteriovenous fistula associated with a spinal perimedullary fistula: Case report. J Neurosurg Spine 2006;4:241245

9. Aminoff MJ, Barnard RO, Logue V. The pathophysiology of spinal vascular malformations. J Neurol Sci 1974;23:255-263

10. Lee CS, Pyun HW, Chae EY, Kim KK, Rhim SC, Suh DC. Reversible aggravation of neurological deficits after steroid medication in patients with venous congestive myelopathy caused by spinal arteriovenous malformation. Interv Neuroradiol 2009; $15: 325-329$

11. Adrianto Y, Yang KH, Koo HW, Park W, Jung SC, Park JE, et al. Concomitant origin of the anterior or posterior spinal artery with the feeder of a spinal dural arteriovenous fistula (SDAVF). $J$ Neurointerv Surg 2016

12. Shi HB, Suh DC, Lee HK, Lim SM, Kim DH, Choi CG, et al. Preoperative transarterial embolization of spinal tumor: Embolization techniques and results. AJNR Am J Neuroradiol 1999;20:2009-2015

13. Suh DC, Kim HS, Baek HJ, Park JW, Kim KK, Rhim SC. Angioarchitecture of Spinal Dural Arteriovenous Fistula-Evaluation with 3D Rotational Angiography. Neurointervention 2012;7: $10-16$

14. Cullen S, Demengie F, Ozanne A, Alvarez H, Mercier PH, Brassier $\mathrm{G}$, et al. The anastomotic venous circle of the base of the brain. Interv Neuroradiol 2005;11:325-332

15. Suh DC, Choi CG, Sung KB, Kim KK, Rhim SC. Spinal osseous epidural arteriovenous fistula with multiple small arterial feeders converging to a round fistular nidus as a target of venous approach. AJNR Am J Neuroradiol 2004;25:69-73 